\title{
Titanium oxide with nanocoolant for heat exchanger application
}

\author{
A. Kottasamy*, K. Kadirgama, Keeran Annamalai, Mohanesan K., \\ D. Ramasamy*, M.M. Noor, M.M. Rahman and M Razali Hanipah
Faculty of Mechanical Engineering, Universiti Malaysia Pahang 26600, Pekan, Pahang, Malaysia
*Email: tk.aravind@yahoo.com, deva@ump.edu.my

Phone: $+60173900324 / 0167580946$

\begin{abstract}
The objective of this paper is to investigate the properties of oil-based nanofluids and produce stable and biodegradable oil-based nanofluids by metal oxide nanoparticles. The cooking oil was used as a base for the nanofluid preparation. Titanium oxide was embedded as the nanoparticles, mixed with cooking oil volume concentration of nanofluids specimens, and labelled as $0.01,0.03,0.05,0.07$, and 0.09 . The study explained the analysis techniques applied to determine the enhancement of thermal properties of nanofluids. The thermal conductivity of nanofluids was studied by heat transfer rate and the overall heat transfer coefficient gained. The metal oxide nanomaterials were mixed with the oil-based fluids in order to prepare the specimens. This research focused on the usage of vegetable oil and titanium oxide nanoparticles mixture to form nanofluids. The results obtained indicated that the nanofluid gave better thermal conductivity than oil-based fluids. The results significantly increased the thermal properties limitation and improved the product reliability. The enhancement of heat transfer rate for $0.09 \%$ of nanofluid volume concentration was increased by $36.25 \%$
\end{abstract}

Keywords: Ethylene Glycol; Long life coolant; Aluminium Oxide; nanoparticles; car radiator.

\section{INTRODUCTION}

Malaysia is a fast developing country with an average of seven percent annual economic growth [1]. Energy consumption is growing rapidly in line with the increase in population and economy [2]. Statistics from Malaysia Energy Commission depicted that the average energy consumption in 1980 increased from 2500 ktoe to 22000 ktoe in 2010 . The rapid growth in energy consumption raises the usage of fossil fuels and also creates climatic concerns including global warming, greenhouse emission and air pollutants. The natural resources such as coal, natural gas, and petroleum which are currently available are also depleting. Therefore, we are in a red alert situation where the resources should be utilised to sustain a better living environment for future generations. Energy conservation is a vital objective of the national economy and will continue to be one in the future. The most effective manner to decrease energy demand is to utilise energy more efficiently [3-6] as in Figure 1. The importance of heat exchangers has increased enormously from the perspective of energy conservation, conversion, recovery, and successful implementation of new energy sources. According to Shah and Sekulic [7], its importance is also increasing from the stance of environmental concerns such as air, water, and thermal 
pollution as well as waste disposal. Heat exchangers are commonly found in the manufacturing industries, transportation, and industrial products [8-10]. Heat exchangers are devices used to transfer heat energy from one fluid to another. Heat exchangers and evaporators in air conditioners and refrigerators are types of heat exchangers commonly found in everyday lives. Boilers and heat exchangers in thermal power plants are examples of large industrial heat exchangers. There are heat exchangers in our automobiles in the form of radiators and oil coolers. Heat exchangers are also abundant in chemical industries as stated by Shah and Sekulic [7]. The cooler fluid absorbs heat from the hotter fluid to reduce its temperature. Heat exchangers differ from mixing chambers in that they prevent the mixture of two fluids involved. In a car radiator, for example, heat is transferred from the hot water flowing through the radiator tubes to the air flowing through the closely spaced thin plates attached to the tubes outside. Heat exchangers are classified according to the transfer processes, number of fluids, degree of surface compactness, construction features, flow arrangements, and heat transfer mechanisms as proved by Shah and Sekulic [7].

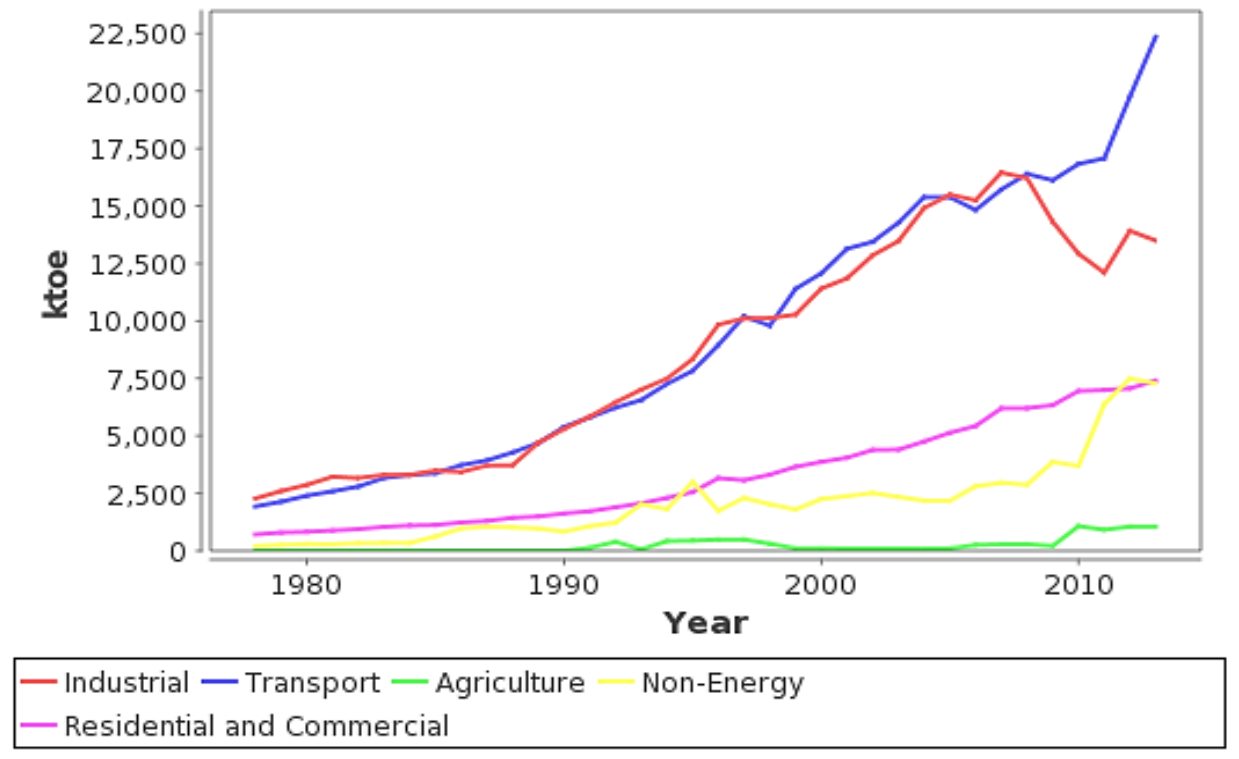

Figure 1. Energy consumption statistics for year 1980 - 2010 [3].

The appropriate design, operation, and maintenance of heat exchangers will ensure energy efficiency and decrease energy loss. Heat exchanger performance may deteriorate with time due to design operations and other interferences such as fouling or scaling. It is necessary to assess the heat exchanger performance periodically to maintain a high efficiency level. Unfortunately, heat exchangers are prone to fouling, since its nature depends on the fluids flowing in and over the tubes. Reduction in heat transfer that is almost consistent has an impact on product cost. Fouling can be defined as accumulation of undesirable substances on a surface. It is classified into the following categories such as particulate fouling, crystallisation fouling, corrosion fouling, bio fouling and chemical reaction fouling [11-14]. Since the 1950s, some efforts have been done on the variation in geometry of heat exchanger apparatus. Although improvement in energy efficiency is possible from the topological and configuration points of view, much more is needed from the perspective of the heat transfer fluid. Further enhancement in heat transfer is always in demand as the operational speed of these devices depends on 
the cooling rate. New technology and advanced fluids with greater potential to improve the flow and thermal characteristics are two options to enhance the heat transfer rate [15]. Working fluid selection is one of most important factors of the effectiveness of a heat exchanger [3]. Current types of fluid that are being used as in heat exchangers are water, ethylene glycol with water, propylene glycol water, seawater, fresh water from lakes, reservoir or river, carbon dioxide, calcium chloride with water, sodium chloride with water, glycerin with water, Freon, mineral oils, and ammonia. The fluid selection is mainly dependent on the condensation temperature. However, the current types of fluids are not efficient as they have low thermal conductivity values and cause problems such as corrosion and bio-fouling. An evolving and new type which is nanofluids is produced by dispersing nano scaled particles into a carrier liquid such as water and ethyl glycol [1619]. Nanofluids can be best suited in heat transfer applications as fluid [20-23]. Friction and heat loss are the main causes of energy loss in mechanical systems. Usage of nanofluid will significantly improve the input energy of the mechanical system. Generally, the base fluid is mixed with metal nano particles such as zinc oxide, titanium dioxide, aluminium oxide, and silicon powder. The thermal conductivity of metal nanoparticles is higher than the base fluid. Metal nanoparticles enhance the thermal properties, especially the thermal conductivity, k of the base fluids they are mixed with. Thermal properties of the nanofluid are mainly dependent on the metal nanoparticle properties. When metal nanoparticles are dispersed into the carrier liquids, the heat transfer efficiency of the fluid compared to the carrier liquid by itself increases [24-28]. Theoretically, the improvement can be up to $350 \%$ because compared to liquid such as water or other organic fluids, metal has a much higher thermal conductivity, no matter what state it stays at. Thus, if using a certain liquid metal or its alloys with low melting point as the fluid, a much higher cooling capability will be achieved. Although current experiments could not prove such high thermal conductivity enhancements, significant increase in the critical heat flux of the fluid has been found $[29,30]$. The objectives of the paper are to investigate the properties of oil-based nanofluids, produce a stable biodegradable oil-based nanofluids by using metal oxide nanoparticles, and investigate the thermal properties of the newly produced nanofluid.

\section{METHODS AND MATERIALS}

\section{Experimental Method}

Nano-particle powders used in this research are titanium dioxide and metal oxide powder. Cooking oil was used as the oil based fluid. The mass of titanium dioxide powder was measured and the cooking oil was mixed together. Then, the mixture was stirred with a magnetic stirrer until the solvent was completely mixed. The mixture was left for a few hours up to one day and its stability was observed. The volume concentration of nanofluid specimens were labelled as 0.01, 0.03, 0.05, 0.07, and 0.09, while three litres of oil were prepared for every volume of concentration. A heat exchanger test rig experiment was carried out. Figure 2 shows the details of the nanofluid preparation. 


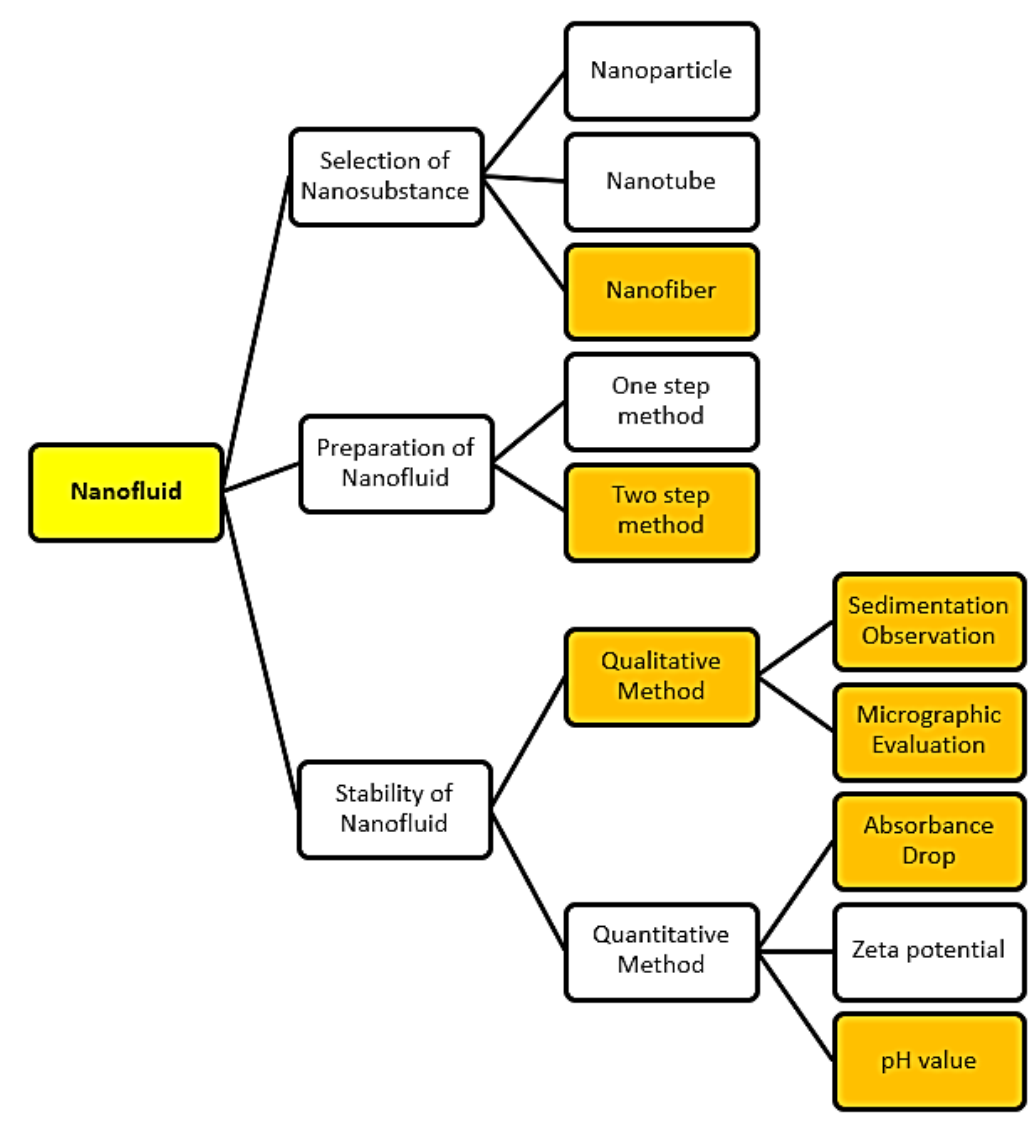

Figrue 2. Nanofluid preparation flowchart.

\section{Experimental Data Analysis}

In this research, the volume of cooking oil used was three litres. Preparation of a large volume of oil is challenging, hence the volume of sample of $500 \mathrm{ml}$ oil was prepared 6 times. Based on the properties of nanoparticles and cooking oil, the volume concentration of nanoparticles was calculated. Volume concentration $(\phi)$ can be calculated by,

$$
\phi=\frac{m_{p} / \rho_{p}}{m_{p} / \rho_{p}+m_{f} / \rho_{f}}
$$

here, $m_{p}=$ mass of nanoparticle; $m_{f}=$ mass of based fluid; $\rho_{p}=$ density of nanoparticle; $\rho_{f}=$ density of base fluid.

Table 1. Mass of nanoparticles powder for $50 \mathrm{ml}$ samples.

\begin{tabular}{lrrrrr}
\hline Volume concentration, \% & 0.01 & 0.03 & 0.05 & 0.07 & 0.09 \\
\hline Nanoparticles Mass, $\mathrm{m}_{\mathrm{p}}, \mathrm{g}$ & 0.0195 & 0.0585 & 0.0975 & 0.1366 & 0.1756 \\
\hline
\end{tabular}

The schematic set up of the test rig is shown in Figure 3. Hot flow referred to the water flow where the heat source was from the transformer, whereas the cold flow referred to nanofluids flow that acted as the coolant agent. Then, the heat transfer rate was determined. The counter flow was chosen due to the difference in temperature between 
the two fluids throughout the exchanger. The outlet temperature of the cold flow was facing the high temperature of the hot flow. This ensured a more uniform heat transfer rate throughout the heat exchanger. Figure 4 shows the heat exchanger used. The calibration was done using known temperatures for the thermocouples in ice water and boilng water.

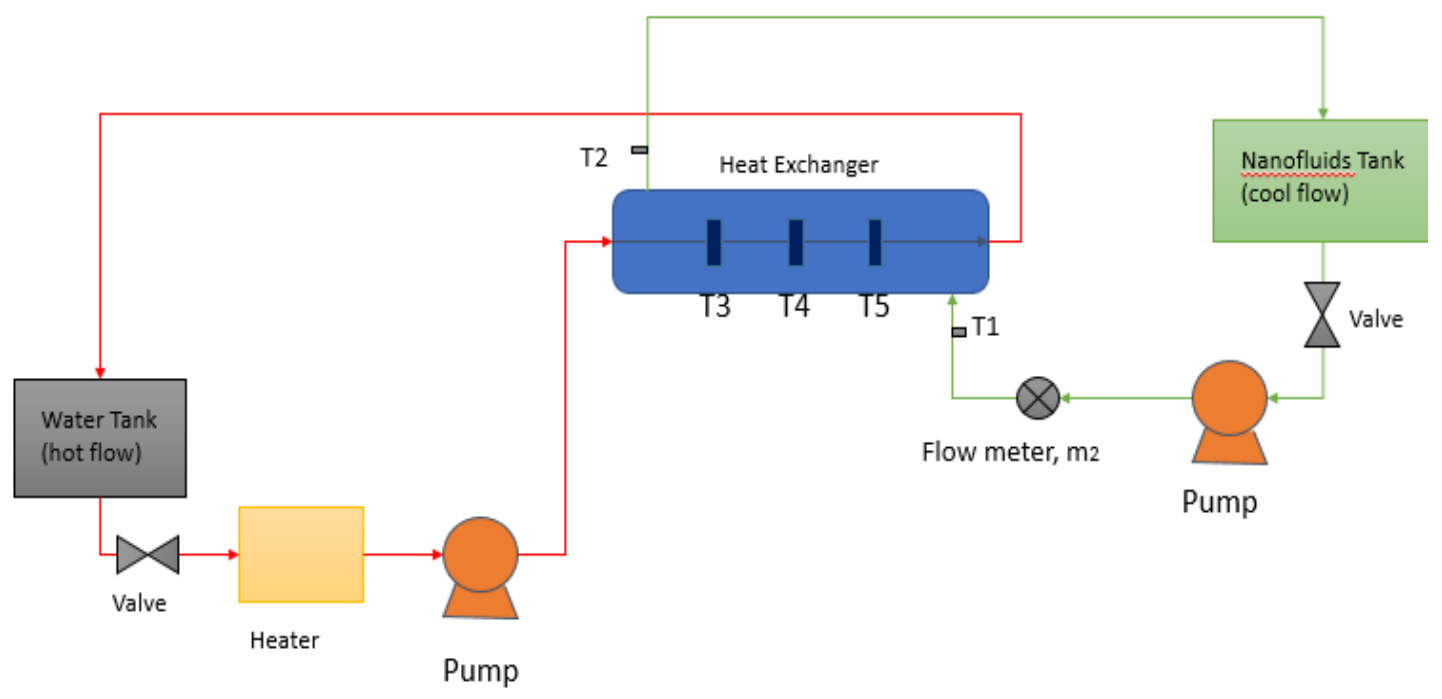

Figure 3. Schematic design of heat exchanger test rig set up.

Heat transfer rate,

$$
Q=\dot{m}_{1} C_{p 1}\left(T_{1}-T_{2}\right)=\dot{m}_{2} C_{p 2}\left(T_{4}-T_{3}\right)
$$

Log mean temperature difference, LMTD,

$$
\Delta T_{l m}=\frac{\left(T_{1}-T_{4}\right)-\left(T_{2}-T_{g}\right)}{\ln \left(\frac{T_{1}-T_{4}}{T_{2}-T_{m}}\right)}
$$

Heat transfer coefficient,

$$
U=\frac{Q}{A_{s} \Delta T_{l m}} ; A_{s}=\text { Surface Area }
$$

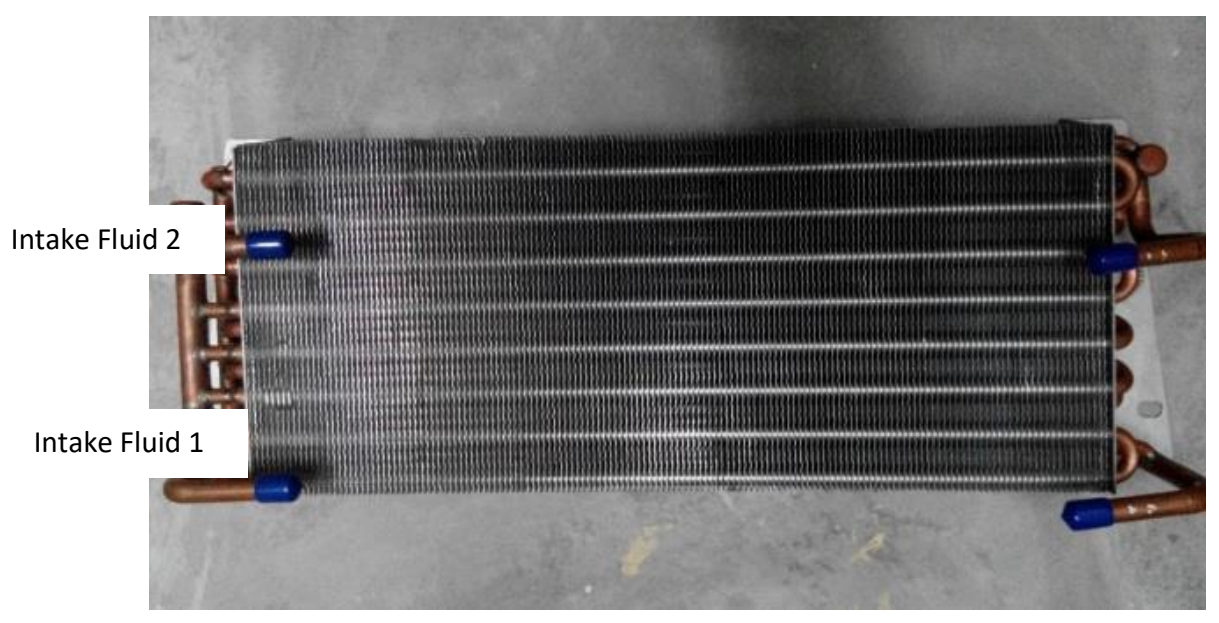

Exit Fluid 2

Figure 4. Heat exchanger that will used. 
In this experiment, the temperature reading was sensed by thermocouples of the Measurement Computing USB-5203 device. The device was used to record the reading of temperature. The nanofluid was left to run throughout the test rig, while the temperature reading was recorded by the device for 30 minutes, after the test rig was switched on. Then, the data collected was analysed by using TracerDAQ and Excel worksheet. This heat exchanger has two inlet and outlet flows for hot flow, thus the thermocouples were installed before the entrance. Besides, there were three more thermocouples that were thermos-pasted at the fin assumed as the surface.

Table 3. Specification of measurement devices

\begin{tabular}{lll}
\hline Measured parameters & Transducer/sensor type & Range \\
\hline Fluid flow rate & Electronic flow meter & $1-150 \mathrm{~L} / \mathrm{min}$ \\
Fluid temperature & K-type thermocouple & $0-1000{ }^{\circ} \mathrm{C}$ \\
\hline
\end{tabular}

\section{RESULTS AND DISCUSSION}

From Figure 5, thermal conductivity of the nanofluids was approximately the same. This was due to the proper mixing obtained while stabilising the fluid in the methodolgy. The stabilised fluid behaved as per the baseline; however, the thermal parts are to be further experimented [31]. There were higher volume concentrations or heat applied, thus clear results can be gained. The trendline demonstrated the inclination of thermal conductivity reading, and this explained that the volume fraction of nanoparticles was the principle factor affecting the thermal conductivity of nanofluids. The $\mathrm{TiO}_{2} /$ palm oil nanofluids were newly developed and improved thermal conductivity, which has the potential in heat transfer fluids performance [32-34].

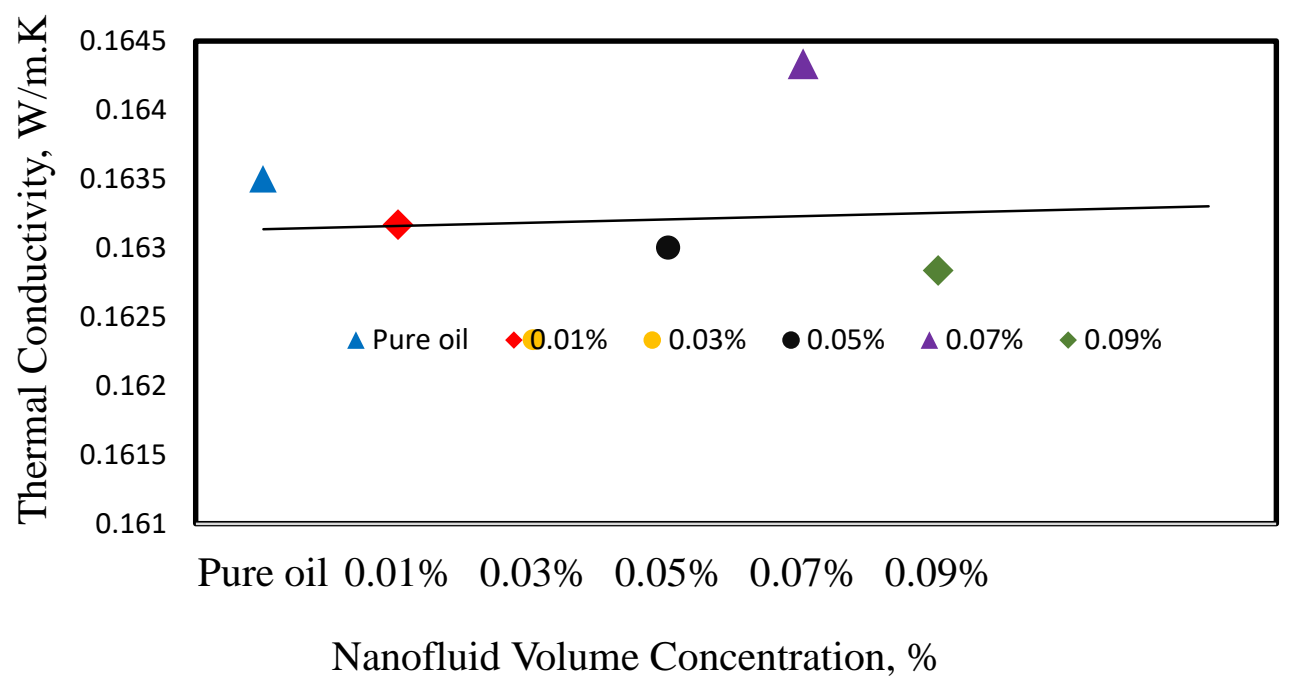

Figure 5. Graph of thermal conductivity, k against nanofluid volume concentration

Figure 6 illustrates the graph of viscosity against different concentrations of nanofluids. The results indicated that the nanoparticles' volume fractions increased with the viscosity of nanofluids as a result of the friction formed between nanoparticles and wall surface. Addition of nanoparticles changed the properties of nanofluids, where more surface friction of nanoparticles existed in palm oil. The main reduction reducing thermal 
heat and a protective layer was created on the surface of the friction materials $[24,35$, 36]. This increased the particle torque and friction loss in the system.

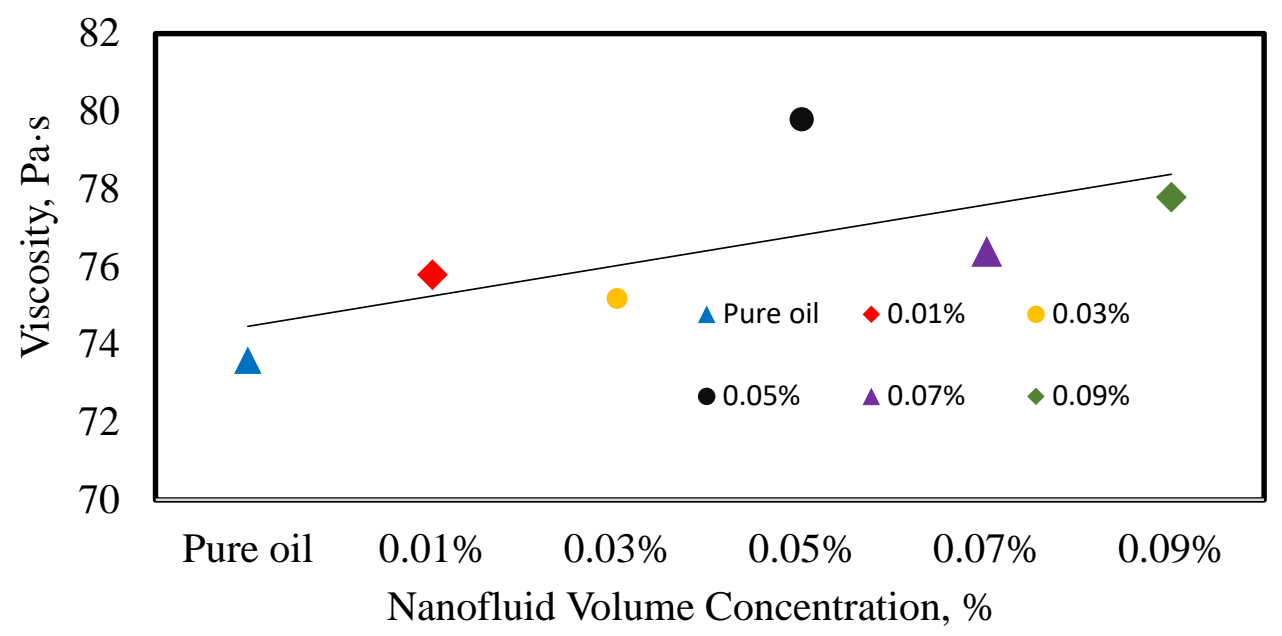

Figure 6. Graph of viscosity against different concentrations of nanofluid.

Figure 7 outlines the seven points of thermocouples that detected the temperatures at a particular point. It was clearly explained that the inlet temperature of hot flow was rapidly higher than the other points. The outlet temperature of hot flow was traced to be lower than inlet flow. This indicated the presence of heat transfer in the heat exchanger. The heat energy was released to the cold flow and surrounding. While for the cold flow, the outlet temperature was sensed to be slightly higher than the inlet temperature. This was as a consequence of heat absorption from the heat sources. Subsequently, the other three points of temperature were detected to vary from each other as the heat was transferring among hot flow and cold flow. However, the three points of mid surface of the heat exchanger were neglected because the results were unstable [37]. The continuous rise was in tandem with heat exchanger operations.

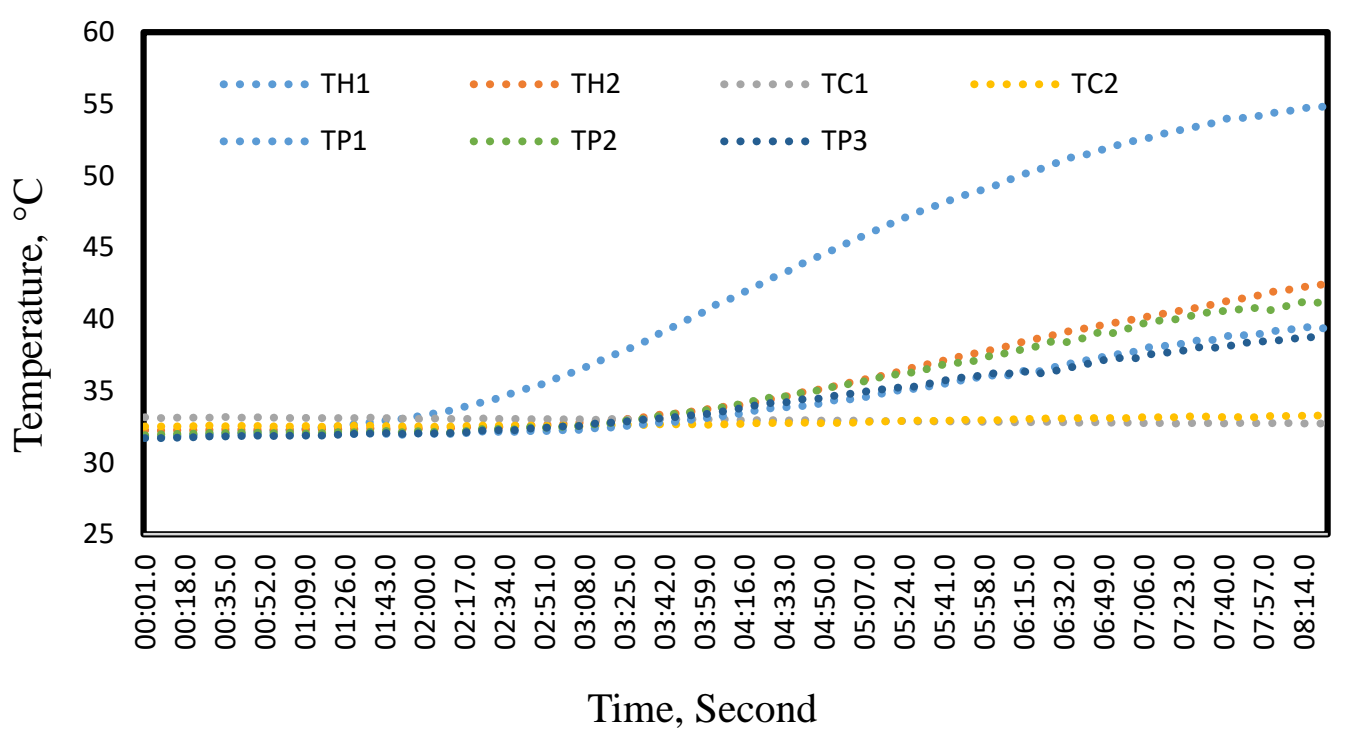

Figure 7. Effect of temperature against time based oil. 
Figure 8 represents the results of the relative heat transfer rate against the $\mathrm{TiO}_{2} / \mathrm{Palm}$ oil nanofluids concentration. The heat transfer rate relatively increased with the increase in concentration of nanofluids. The increase was because the surface area of the nanoparticle increased as the concentration was increased [38]. The heat transported by this addition was enhanced and used for improvements. The enhancement of heat transfer rate for $0.09 \%$ of nanofluid volume concentration was increased by $36.25 \%$ than the base oil. This result proved that there was more heat energy transfer from the nanofluids. There was better heat conductivity in the nanofluids compared to base oil, because the nanoparticles were within it. The heat energy can be easily absorbed and released from the metal molecules [39].

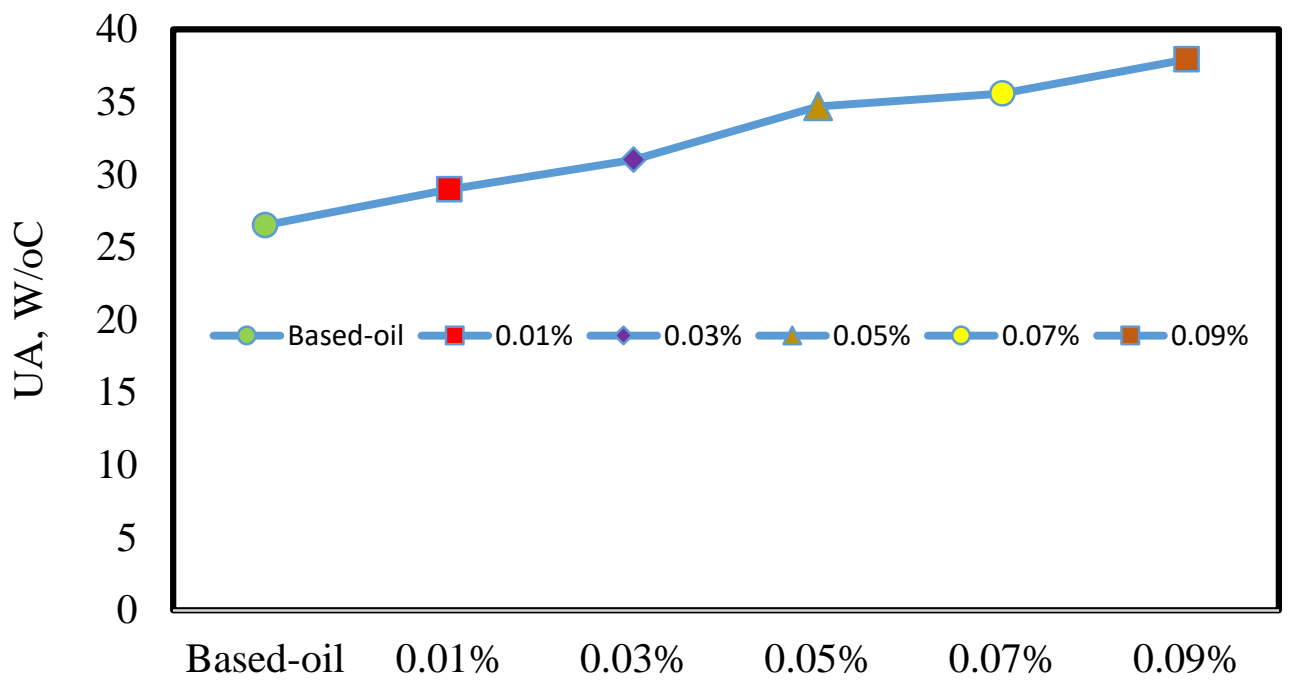

Nanofluid Volume Concentration, \%

Figure 8. Graph of UA against different concentrations of nanofluids

\section{CONCLUSIONS}

There were limitations in this research, where the fabrication of heat exchanger test rig needed to be refined by better designs. The pumps should be exchanged to a higher flow rate pump, thus the variant of flow rate of nanofluids can be investigated. Besides that, the friction of the nanofluids in the heat exchanger can be studied if the flow rate was faster and turbulent. Since the tank was used to heat up at high temperature, it might be damaged.Thus, the tank needed to be changed to a metal tank that can withstand high temperature. In the research, the heater was used for only five minutes because it was unable to go higher than that, since the heater's handle has started to melt. The heater needed a dipped heater coil in order to allow constant heat distribution inside the tank. If the heater was able to function for a longer period of time, extra results can be investigated and studied. The enhancement of heat transfer rate for $0.09 \%$ of nanofluid volume concentration was increased by $36.25 \%$. 


\section{ACKNOWLEDGEMENTS}

The authors would like to thank the Faculty of Mechanical Engineering in Universiti Malaysia Pahang (RDU160319) and Malaysian Higher Education Ministry (RDU151311) for providing financial support and facilities for the research.

\section{REFERENCES}

[1] Grier KB, Tullock G. An empirical analysis of cross-national economic growth, 1951-1980. Journal of monetary economics. 1989;24:259-76.

[2] Islam F, Shahbaz M, Ahmed AU, Alam MM. Financial development and energy consumption nexus in Malaysia: a multivariate time series analysis. Economic Modelling. 2013;30:435-41.

[3] Ong H, Mahlia T, Masjuki H. A review on energy scenario and sustainable energy in Malaysia. Renewable and Sustainable Energy Reviews. 2011;15:639-47.

[4] Rahman NA, Abdullah S, Abdullah MF, Zamri WFH, Omar MZ, Sajuri Z. Energy absorption capability and deformation of laminated panels for armoured vehicle materials. International Journal of Automotive and Mechanical Engineering. 2016;13:3657-68.

[5] Azad AK, Rasul MG, Mofijur M, Bhuiya MMK, Mondal SK, Sattar MK. Energy and waste management for petroleum refining effluents: A case study in Bangladesh. International Journal of Automotive and Mechanical Engineering. 2015;11:2170-87.

[6] Ayu TT, Hailu MH, Hagos FY, Atnaw SM. Energy audit and waste heat recovery system design for a cement rotary kiln in Ethiopia: A case study. International Journal of Automotive and Mechanical Engineering. 2015;12:2983-3002.

[7] Shah RK, Sekulic DP. Fundamentals of heat exchanger design: John Wiley \& Sons; 2003.

[8] Saidur R, Ahamed J, Masjuki H. Energy, exergy and economic analysis of industrial boilers. Energy Policy. 2010;38:2188-97.

[9] Sahid N, Rahman M, Kadirgama K, Ramasamy D, Maleque M, Noor M. Experimental investigation on the performance of the $\mathrm{TiO}^{2}$ and $\mathrm{ZnO}$ hybrid nanocoolant in ethylene glycol mixture towards AA6061-T6 machining. International Journal of Automotive and Mechanical Engineering. 2017;14.

[10] Ramachandran K, Yeesvaran B, Kadirgama K, Ramasamy D, Ghani SAC, Anamalai K. State of art of cooling method for dry machining. MATEC Web of Conferences: EDP Sciences; 2017. p. 01015.

[11] Epstein N. Fouling in heat exchangers. Sixth International Heat Transfer Conference1977. p. 235-53.

[12] Kadirgama K, Ramasamy D, El-Hossein KA, Hwa K, Kadirgama G. Assessment of alternative methods of preparing internal combustion engine cylinder bore surfaces for frictional improvement. Journal of the Brazilian Society of Mechanical Sciences and Engineering. 2017:1-15.

[13] Hussein AM, Kadirgama K, Sharma K, Ramasamy D, Bakar R. Heat Transfer Enhancement with Nanofluids for Automotive Cooling. Engineering Applications of Nanotechnology: Springer International Publishing; 2017. p. 71100. 
[14] Hisham S, Kadirgama K, Ramasamy D, Noor M, Amirruddin A, Najafi G, et al. Waste cooking oil blended with the engine oil for reduction of friction and wear on piston skirt. Fuel. 2017.

[15] Bhimani V, Ratho P, Sorathiya A. Experimental study of heat transfer enhancement using water based nanofluids as a new coolant for car radiators. International Journal of Emerging Technology and Advanced Engineering. 2013;3:295-302.

[16] Sahid NSM, Rahman MM, Kadirgama K, Ramasamy D, Maleque MA, Noor MM. Experimental investigation on the performance of the $\mathrm{TiO}_{2}$ and $\mathrm{ZnO}$ hybrid nanocoolant in ethylene glycol mixture towards AA6061-T6 machining. International Journal of Automotive and Mechanical Engineering. 2017;14:391326.

[17] Hussein AM, Noor MM, Kadirgama K, Ramasamy D, Rahman MM. Heat transfer enhancement using hybrid nanoparticles in ethylene glycol through a horizontal heated tube. International Journal of Automotive and Mechanical Engineering. 2017;14:4183-95.

[18] Yogeswaran M, Kadirgama K, Rahman MM, Devarajan R. Temperature analysis when using ethylene-glycol-based tio2 as a new coolant for milling. International Journal of Automotive and Mechanical Engineering. 2015;11:2272-81.

[19] Abdullah A, Mohamad IS, Bani Hashim AY, Abdullah N, Wei PB, Md. Isa MH, et al. Thermal conductivity and viscosity of deionised water and ethylene glycolbased nanofluids. Journal of Mechanical Engineering and Sciences. 2016;10:2249-61.

[20] Najiha MS, Rahman MM, Kadirgama K. Parametric optimization of end milling process under minimum quantity lubrication with nanofluid as cutting medium using pareto optimality approach. International Journal of Automotive and Mechanical Engineering. 2016;13:3345-60.

[21] Usri NA, Azmi WH, Mamat R, Abdul Hamid K. Forced convection heat transfer using water- ethylene glycol (60:40) based nanofluids in automotive cooling system. International Journal of Automotive and Mechanical Engineering. 2015;11:2747-55.

[22] Abdolbaqi MK, Azwadi CSN, Mamat R, Azmi WH, Najafi GN. Nanofluids heat transfer enhancement through straight channel under turbulent flow. International Journal of Automotive and Mechanical Engineering. 2015;11:2294-305.

[23] Hussein AM, Bakar RA, Kadirgama K, Sharma KV. Experimental measurements of nanofluids thermal properties. International Journal of Automotive and Mechanical Engineering. 2013;7:850-63.

[24] Choi C, Yoo H, Oh J. Preparation and heat transfer properties of nanoparticle-intransformer oil dispersions as advanced energy-efficient coolants. Current Applied Physics. 2008;8:710-2.

[25] Zainal Abidin S, Mohamad S, Bani Hashim AY, Abdullah N, Hafiz MIM, Masripan NAB, et al. Investigation of thermal characteristics of CNF-based nanofluids for electronic cooling applications. Journal of Mechanical Engineering and Sciences. 2016;10:2336-49.

[26] Najiha M, Rahman M, Kadirgama K. Performance of water-based $\mathrm{TiO}_{2}$ nanofluid during the minimum quantity lubrication machining of aluminium alloy, AA6061T6. Journal of Cleaner Production. 2016; In press.

[27] Zakaria I, Michael Z, Mohamed WANW, Mamat AMI, Azmi WH, Mamat R, et al. A review of nanofluid adoption in polymer electrolyte membrane (PEM) fuel 
cells as an alternative coolant. Journal of Mechanical Engineering and Sciences. 2015;8:1351-66.

[28] Hussein AM, Sharma KV, Bakar RA, Kadirgama K. Heat transfer enhancement with nanofluids - A Review. Journal of Mechanical Engineering and Sciences. 2013;4:452-61.

[29] Das SK, Choi SU, Yu W, Pradeep T. Nanofluids: science and technology: John Wiley \& Sons; 2007.

[30] Estellé P, Halelfadl S, Maré T. Thermophysical properties and heat transfer performance of carbon nanotubes water-based nanofluids. Journal of Thermal Analysis and Calorimetry. 2017;127:2075-81.

[31] Yu W, France DM, Choi SU, Routbort JL. Review and assessment of nanofluid technology for transportation and other applications. Argonne National Laboratory (ANL); 2007.

[32] Ebrahimnia-Bajestan E, Moghadam MC, Niazmand H, Daungthongsuk W, Wongwises S. Experimental and numerical investigation of nanofluids heat transfer characteristics for application in solar heat exchangers. International Journal of Heat and Mass Transfer. 2016;92:1041-52.

[33] Kurhe ED, Kale SS, Purane AD, Kale SS, Ransing SR. Heat enhancement using tio2-nano fluid in automotive cooling system. 2016.

[34] Ramasamy D, Zainal Z, Bakar R, Kadirgama K. Mass fraction burn comparison of compressed natural gas and gasoline. Applied Mechanics and Materials: Trans Tech Publ; 2014. p. 442-6.

[35] Hutchings I, Shipway P. Tribology: friction and wear of engineering materials: Butterworth-Heinemann; 2017.

[36] Albadr J, Tayal S, Alasadi M. Heat transfer through heat exchanger using Al $2 \mathrm{O}$ 3 nanofluid at different concentrations. Case Studies in Thermal Engineering. 2013;1:38-44.

[37] Liu P, Nasr MR, Ge G, Alonso MJ, Mathisen HM, Fathieh F, et al. A theoretical model to predict frosting limits in cross-flow air-to-air flat plate heat/energy exchangers. Energy and Buildings. 2016;110:404-14.

[38] Bayomy A, Saghir M. Experimental Investigation of Using $\gamma$-Al2O3-Water Nanofluid Flow in Aluminum Foam Heat Sink. ICTEA: International Conference on Thermal Engineering2017.

[39] Chieruzzi M, Miliozzi A, Torre L, Kenny JM. Nanofluids with Enhanced Heat Transfer Properties for Thermal Energy Storage. Intelligent Nanomaterials. 2016:295-359. 